\title{
Application of mixed models in sensory analysis of probiotic mango juice
}

\author{
Aplicação de modelos mistos na análise sensorial de suco probiótico de manga \\ Aplicación de modelos mixtos em análisis sensorial de jugo de mango probiótico
}

Received: 03/13/2021 | Reviewed: 03/20/2021 |Accept: 03/20/2021 | Published: 03/30/2021

\author{
Andreza Cândido Mendes \\ ORCID: https://orcid.org/0000-0001-7370-8112 \\ Universidade Estadual de Maringá, Brazil \\ E-mail: andrezacandido.91@gmail.com \\ Raquel Guttierres Gomes \\ ORCID: https://orcid.org/0000-0003-2420-5134 \\ Universidade Estadual de Maringá, Brazil \\ E-mail: rgutti02@gmail.com \\ Andresa Carla Feihrmann \\ ORCID: https://orcid.org/0000-0003-2389-0467 \\ Universidade Estadual de Maringá, Brazil \\ E-mail: andresafeihrmann@gmail.com \\ Diogo Francisco Rossoni \\ ORCID: https://orcid.org/0000-0001-6337-6628 \\ Universidade Estadual de Maringá, Brazil \\ E-mail: dfrossoni@uem.br
}

\begin{abstract}
The present work aimed to apply the mixed models to the results of the sensory analysis of probiotic mango juice with Bifidobacterium animalis ssp. Lactis - BB-12. Physicochemical analyzes ( $\mathrm{pH}$, titratable acidity, total solids, and color parameters), the viability of probiotics was performed, and for sensory analysis, the affective method and the acceptance test were used, where the attributes were analyzed in mango juices with and without probiotic. The encapsulated probiotic remained viable in the juice, and the physicochemical analysis showed results as expected for this type of product. In the results of the random effect of the sensorial analysis, there was a great variability of panelists for the aroma attribute, standing out as the best attribute both for mango juice with probiotics and for juice without probiotics. In the acceptance test, the panelists showed a greater preference for mango juice without probiotics, however, concerning mango juice with probiotics, the panelists liked the aroma and showed a satisfactory purchase intention. Based on the results, it can be concluded that with the use of the mixed models it was possible to estimate the variability between the panelists and their scores.
\end{abstract}

Keywords: Bifidobacterium animalis ssp. Lactis; Viability; Functional food.

\section{Resumo}

O presente trabalho teve como objetivo aplicar modelos mistos aos resultados da análise sensorial de suco probiótico de manga com Bifidobacterium animalis ssp. Lactis - BB-12. Análises físico-químicas (pH, acidez titulável, sólidos totais e parâmetros de cor), a viabilidade dos probióticos foram realizadas, e para a análise sensorial foram utilizados o método afetivo e o teste de aceitação, onde os atributos foram analisados em sucos de manga com e sem probiótico. O probiótico encapsulado permaneceu viável no suco, e as análises físico-químicas mostraram os resultados esperados para esse tipo de produto. Nos resultados do efeito aleatório da análise sensorial, houve grande variabilidade de provadores para o atributo aroma, destacando-se como o melhor atributo tanto para suco de manga com probióticos quanto para suco sem probióticos. No teste de aceitação, os provadores demonstraram maior preferência pelo suco de manga sem probióticos, porém, em relação ao suco de manga com probióticos, os provadores gostaram do aroma e demonstraram intenção de compra satisfatória. Com base nos resultados, pode-se concluir que com a utilização dos modelos mistos foi possível estimar a variabilidade entre os painelistas e seus escores.

Palavras-chave: Bifidobacterium animalis ssp. Lactis; Viabilidade; Alimento funcional.

\section{Resumen}

El presente trabajo tuvo como objetivo aplicar los modelos mixtos a los resultados del análisis sensorial de jugo de mango probiótico con Bifidobacterium animalis ssp. Lactis - BB-12. Se realizaron análisis fisicoquímicos (pH, acidez titulable, sólidos totales y parámetros de color), la viabilidad de los probióticos, y para el análisis sensorial se utilizó el método afectivo y la prueba de aceptación, donde se analizaron los atributos en jugos de mango con y sin probiótico. El probiótico encapsulado permaneció viable en el jugo y el análisis fisicoquímico arrojó resultados esperados para este tipo de producto. En los resultados del efecto aleatorio del análisis sensorial, hubo una gran variabilidad de panelistas para el atributo aroma, destacándose como el mejor atributo tanto para el jugo de mango con probióticos como para el jugo sin probióticos. En la prueba de aceptación, los panelistas mostraron una mayor preferencia por el 
jugo de mango sin probióticos, sin embargo, en cuanto al jugo de mango con probióticos, a los panelistas les gustó el aroma y mostraron una intención de compra satisfactoria. Con base en los resultados, se puede concluir que con el uso de los modelos mixtos fue posible estimar la variabilidad entre los panelistas y sus puntajes.

Palabras clave: Bifidobacterium animalis ssp. Lactis; Viabilidad; Comida funcional.

\section{Introduction}

Over the years, consumers are becoming increasingly demanding about the consumption of healthier and safer products, without losing the characteristic of the product, such as flavor (Oliveira et al., 2020). Recently with the advancement of technology, companies are increasingly committed to meeting consumer demands. Targeting healthy products, we can notice a growth in the use of probiotics in foods, which leads to a growing interest in functional foods (Guimarães et al., 2020).

The use of people as measuring instruments whether they are simple panelists to participate in a market study, trained or untrained tasters, integrating a panel of tasters is increasingly important in the development of food and beverage products (Ares \& Varela, 2017).

Probiotics are living organisms that, when administered in adequate amounts, confer benefits to the health of the host and can act on intestinal bacterial balance, control cholesterol and diarrhea, and reduce the risk of cancer. Among the various genres that integrate probiotic cultures, Bifidobacterium and Lactobacillus stand out (Pimentel et al., 2015).

The incorporation of probiotic cultures belonging to the genera Bifidobacterium and Lactobacillus in dairy products is a widespread practice within the food industry. However, plant matrices, such as fruit juices, have been studied as potential carriers for these microorganisms (Costa et al., 2013). The development of new products added from these crops to expand this market and consumer acceptance has increased, as not all people can consume or appreciate dairy products (Kingwatee et al., 2015). Thus, the food industries have sought to increase versatility in the consumption of different forms of food without losing the basic properties of providing nutrition and ensuring health (Anekella \& Orsat, 2012).

However, one of the major technological challenges in the use of probiotic microorganisms is to maintain the viability of the bacteria during processing and storage, since many probiotic bacteria are sensitive to exposure to oxygen, heat, and acids. An alternative to maintaining the viability of microorganisms has been the use of microencapsulation (Miranda et al., 2019).

The literature points out studies of juices with microencapsulated probiotic microorganisms, but most are focused on viability, characterization, and storage time (Pereira et al., 2011; Kingwatee et al., 2015; Prates et al., 2020). Concerning the areas of sensory analysis and consumer analysis, there is a lot to explore by sensorily analyzing a new product with probiotics, with the use of other statistical models, such as mixed models that are more suitable for analyzing sensory and consumer data (Brockhoff et al., 2015).

Linear mixed-effects models are tools for modeling continuous correlated hierarchical/multilevel data. In the last decades, these models have become increasingly prominent in various fields. Several software packages, both commercial and open-source, can offer these types of templates (Kuznetsova et al., 2015).

In sensory studies, variance analysis (ANOVA) techniques are generally applied to extract important product information based on their attributes. The mixed model uses both random and fixed effects in its method. They are an integral part of the statistical analysis of sensory and consumption data (Podenphant et al., 2019). Many researchers prefer to consider the panelists' effect as a random effect, this means that panelists are considered random representatives of a population (Naes et al., 2010).

In this context, the present work aimed to study the application of the mixed model to the results of sensory analysis of encapsulated probiotic mango juice.

\section{Material e Methods}




\subsection{Encapsulation of Bifidobacterium BB12 by spray dryer}

The Bifidobacterium animalis ssp. Lactis - BB-12 (Chr. Hansen, Honsholm, Denmark) was encapsulated using sodium alginate (Sigma-Aldrich ${ }^{\circledR}$, Brazil), and xanthan gum (Danisco $\left.{ }^{\circledR}\right)$ as an encapsulating agent. The solution was prepared with peptone water $(938.8 \mathrm{~mL}), 30 \mathrm{~g}$ of sodium alginate, and $5 \mathrm{~g}$ of xanthan gum and sterilized in an autoclave. Then, $7 \mathrm{~g}$ of Bifidobacterium BB-12 was added to the sterile solution. The microencapsulation process was performed in a spray dryer LM MSD 1.0 (Labmaq, São Paulo, Brazil) with constant air, an inlet temperature of $130^{\circ} \mathrm{C}$, and the output temperature $93{ }^{\circ} \mathrm{C}$. The equipment was fed with the encapsulating solution through a peristaltic pump, with a feed flow of $0.40 \mathrm{~L} \mathrm{~h}^{-1}$, the drying air pressure of $3 \mathrm{bar}$, and the drying airflow at $30 \mathrm{~L} \mathrm{~min}^{-1}$. The powder was collected at the base of the cyclone with a previously autoclaved glass bottle (Terçariol et al., 2020).

\subsection{Addition of microcapsules in mango juice}

The mango juice used was the Purity Néctar (Cocamar, Maringá, Brazil), in its formulation contained water, 40\% mango pulp, sugar, aroma, citric acid, ascorbic acid, and guar gum. $12 \mathrm{~g}$ of encapsulated probiotic containing Bifidobacterium BB-12 were added in $1.5 \mathrm{~L}$ of mango juice, then the juice was homogenized in a beaker with glass stick, previously sterilized, and kept refrigerated $\left(5{ }^{\circ} \mathrm{C}\right)$ until the analysis. The initial cell counts of Bifidobacterium BB12 was $7 \log \mathrm{CFU} \mathrm{mL}^{-1}$. For the control treatment, mango juice without probiotics was used.

\subsection{Physicochemical analyses}

The $\mathrm{pH}$ determination in the juice samples with and without probiotic was performed in a digital pH Ft-p21 (HANNA Instruments), calibrated with $\mathrm{pH}$ solutions 4.0 and 7.0. The analysis was performed in triplicate, and measured on the 1st, 6th, and 19th day, to monitor the quality of the product.

The titratable acidity was determined according to AOAC (2004) and expressed as a percentage of citric acid. The analysis was performed in triplicate, and measured on the 1st, 6th, and 19th day, to monitor the quality of the product.

The determination of total soluble solids ( ${ }^{\circ}$ Brix) was determined using a digital refractometer HI96801 (HANNA Instruments) and the determination of the total solids was determined according to AOAC (2004). The analysis was performed in triplicate.

The color was determined by direct reflectance reading of the parameters $L^{*}$ (luminosity), $\mathrm{a}^{*}$ (red-green component), and $b^{*}$ (yellow-blue component) in the colorimeter (Konica Minolta, CR-400, Japan). The juice samples were transferred to a petri dish for readings. The analysis was performed in triplicate, and measured on the 1st and 19th day, to monitor the quality of the product.

\subsection{Viability of probiotics microorganisms}

The probiotics viability was determined both in the microparticles and in mango juice on the day of sensory analysis. Decimal dilutions were made and depth plated in a specific Bifidobacterium ssp. medium (BSM, Sigma), and incubation under anaerobic conditions (Anaerobic) at $37^{\circ} \mathrm{C}$ for 48 hours, according to the methodology of IDF (2007). The results were expressed in $\log \mathrm{CFU} \mathrm{mL} \mathrm{m}^{-1}$.

\subsection{Sensory analysis}

This project was approved by the Ethics committee of the State University of Maringá under number 22362719.0.0000.0104. Sensory acceptance and purchase intention tests were performed seven days after probiotic mango juice production with a group of 92 untrained panelists, who were randomly selected at the State University of Maringá. The 
attributes selected for analysis were appearance, aroma, flavor, and overall impression, by affective test on an unstructured hedonic scale of nine points. White light was used for evaluation and $20 \mathrm{~mL}$ of the samples (with probiotics and without probiotics) were served in disposable cups and coded with three random numbers.

The panelists received along with the samples an evaluation form, with an unstructured hedonic scale, where 9 corresponds to "I liked very much" and 1, "I disliked very much", along with 5 categories for purchase intention, corresponding respectively: 5, "I would certainly buy" and 1, "I certainly would not buy" (Meilgaard et al., 1988).

\subsection{Statistical analysis}

The data obtained for $\mathrm{pH}$, titratable acidity, and color were analyzed utilizing linear models of mixed effect, where the variable "day" is the random effect and the variable "sample" is the fixed effect, post-hoc comparisons were made using the Satterthwaite method with a significance level of $5 \%$. ${ }^{\circ}$ Brix and total solids were performed by $\mathrm{t}$-student test, with a significance level of 5\%, performed in the RStudio version 3.6.1 program (R Core Team, 2019).

The data obtained in the sensory analysis were analyzed utilizing linear models of mixed effect applying the LmerTest package, where the attribute is the response variable, the sample is the fixed effect and the panelists is the random effect, posthoc comparisons were made through the Satterthwaite method with a significance level of 5\%, performed in the RStudio version 3.6.1 program (R Core Team, 2019).

\section{Results}

\subsection{Physicochemical analysis}

Table 1 shows the model ANOVA for the parameters $\mathrm{pH}$, titratable acidity, and color. The results of the $p$-values showed that there is a significant difference at the level of $5 \%$ only for $\mathrm{pH}$, titratable acidity, and $\mathrm{L}^{*}$ parameter (luminosity). Furthermore, the F values indicate that the variability of the groups' means is large, except for the parameter $\mathrm{a}^{*}$ that obtained a low $\mathrm{F}$ value, showing that the variability of this group is lower.

Table 1. Results of ANOVA Type III by Satterthwaite method, for $\mathrm{pH}$, titratable acidity and color ( $\mathrm{L}^{*}, \mathrm{a}^{*}$ and $\left.\mathrm{b}^{*}\right)$.

\begin{tabular}{cccccc}
\hline & & NumDF & DenDF & $\mathbf{F}$ & $\boldsymbol{p}$-value \\
\hline $\mathbf{p H}$ & Treatment & 1 & 20 & 1792.2 & $<0.001$ \\
titratable acidity & Treatment & 1 & 18.23 & 561.65 & $<0.001$ \\
$\mathbf{L}^{*}$ & Treatment & 1 & 9 & 53.11 & $<0.001$ \\
$\mathbf{a}^{*}$ & Treatment & 1 & 9 & 0.0002 & 0.9903 \\
$\mathbf{b}^{*}$ & Treatment & 1 & 9 & 4.68 & 0.0586 \\
\hline
\end{tabular}

NumDF $=$ degrees of freedom of the numerator; DenDF $=$ degrees of freedom of the denominator. Source: Authors.

The means values of physicochemical analyses are presented in Table 2. The addition of probiotic microencapsulated Bifidobacterium BB-12 caused an increase in $\mathrm{pH}$ and a reduction in titratable acidity, ${ }^{\circ}$ Brix, and total solids.

As for the color parameters presented, only the luminosity $\left(\mathrm{L}^{*}\right)$ between the juices had a significant difference, while the parameters $\mathrm{a}^{*}$ and $\mathrm{b}^{*}$ were equal between the juices, tending to green $\left(\mathrm{a}^{*}\right)$ and yellow $\left(\mathrm{b}^{*}\right)$.

Table 2. Results of physicochemical analyses performed in mango juices with probiotic and without probiotic. 


\section{Physicochemical analysis}

\begin{tabular}{|c|c|c|c|c|c|c|c|}
\hline \multirow[t]{2}{*}{ Treatments } & \multirow{2}{*}{ pH } & \multirow{2}{*}{${ }^{\circ}$ Brix } & \multirow{2}{*}{$\begin{array}{c}\text { TS } \\
(\mathrm{g} / \mathbf{1 0 0 g})\end{array}$} & \multirow{2}{*}{$\begin{array}{l}\text { Acidity (\%) } \\
\text { citric acid) }\end{array}$} & \multicolumn{3}{|c|}{ Color } \\
\hline & & & & & $\mathbf{L}^{*}$ & $\mathbf{a}^{*}$ & $\mathbf{b}^{*}$ \\
\hline $\begin{array}{l}\text { Mango juice } \\
\text { without } \\
\text { probiotic }\end{array}$ & $3.86^{\mathrm{a}}$ & $11.62^{\mathrm{a}}$ & $0.53^{\mathrm{a}}$ & $0.55^{\mathrm{a}}$ & $30.00^{\mathrm{a}}$ & $-3.34^{a}$ & $22.71^{\mathrm{a}}$ \\
\hline $\begin{array}{l}\text { Mango juice } \\
\text { with probiotic }\end{array}$ & $4.34^{\mathrm{b}}$ & $11.05^{\mathrm{b}}$ & $0.46^{\mathrm{b}}$ & $0.41^{\mathrm{b}}$ & $38.58^{\mathrm{b}}$ & $-3.33^{\mathrm{a}}$ & $25.87^{\mathrm{a}}$ \\
\hline
\end{tabular}

TS $=$ Total solids. $\mathrm{L}^{*}$ ranging from 0 (black) to 100 (white); $\mathrm{a}^{*}$ ranging from red (+a*) to green (-a*) and $\mathrm{b}^{*}$ ranging from yellow (+b*) to blue (-b*). Values followed by equal letters in the same column indicate no significant difference between treatments at the level of $5 \%$ by the Satterthwaite method. Source: Authors.

\subsection{Viability of probiotics microorganisms}

Regarding the viability analysis, both the microcapsules and the mango juice presented viable Bifidobacterium -BB12 cells results being above $\log 13 \mathrm{CFU} \mathrm{mL} \mathrm{m}^{-1}$ and $\log 12 \mathrm{CFU} / \mathrm{mL}^{-1}$, respectively.

\subsection{Sensory analysis}

According to Table 3, it is possible to observe the ANOVA for each attribute evaluated in the sensory analysis. The appearance and overall impression have a high $\mathrm{F}$ value, indicating great variability of the group means. The $\mathrm{F}$ value of the aroma and flavor were low, presenting a small variability of the means of the groups.

Table 3. Results of ANOVA Type III by the Satterthwaite method, related to the attributes appearance, aroma, flavor and overall impression.

\begin{tabular}{cccccc}
\hline & & NumDF & DenDF & F & $p$-value \\
\cline { 3 - 5 } Appearance & Sample & 1 & 90 & 126.89 & $<0.001$ \\
Aroma & Sample & 1 & 90 & 21.55 & $<0.001$ \\
$\begin{array}{l}\text { Flavor } \\
\begin{array}{l}\text { Overall } \\
\text { impression }\end{array}\end{array}$ & Sample & 1 & 90 & 35.94 & $<0.001$ \\
\hline \multicolumn{2}{l}{ NumDF = degrees of freedom of the numerator; DenDF = degrees of freedom of the denominator. Source: Authors. }
\end{tabular}

The results of the sensory analysis of mango juice acceptance are presented in Table 4. Regarding the mango juice without probiotics, the values obtained were higher for all attributes, indicating that the panelists "liked moderately". And in the purchase intention, the panelists indicated that would "certainly buy the product". In probiotic juice, it is observed that the overall appearance and impression as a score were low indicating that the panelists "disliked slightly". About the aroma, the panelists "liked it slightly", and the flavor "neither liked nor disliked". In the purchase intention, the panelists were in doubt whether or not to buy the product.

Table 4. Average values of the scores obtained in the sensory analysis for each attribute of the different samples. 


\section{Parameters}

\begin{tabular}{|c|c|c|c|c|c|}
\hline Treatments & Appearance & Aroma & Flavor & $\begin{array}{c}\text { Overall } \\
\text { impression }\end{array}$ & $\begin{array}{l}\text { Purchase } \\
\text { intention }\end{array}$ \\
\hline $\begin{array}{c}\text { Mango juice without } \\
\text { probiotic }\end{array}$ & $7.32^{\mathrm{b}}$ & $7.48^{\mathrm{b}}$ & $7.06^{\mathrm{b}}$ & $7.30^{\mathrm{b}}$ & $4.86^{\mathrm{b}}$ \\
\hline $\begin{array}{c}\text { Mango juice with } \\
\text { probiotic }\end{array}$ & $4.36^{\mathrm{a}}$ & $6.12^{\mathrm{a}}$ & $5.40^{\mathrm{a}}$ & $4.86^{\mathrm{a}}$ & $3.35^{\mathrm{a}}$ \\
\hline
\end{tabular}

Values followed by equal letters in the same column indicate no significant difference between treatments at the level of $5 \%$ by the Satterthwaite method. Source: Authors.

Table 5 contains the estimates of the random and fixed effects of the adjusted model, in which the response variable is each attribute (appearance, aroma, flavor, and overall impression), the fixed effect is the samples and the random effect is the panelists.

In the sensory analysis, the appearance attribute reached the note 4.36 for the juice with probiotic and 7.32 for the juice without probiotic, in the random effect the appearance presented a variability of the panelists of 0.80 and a standard deviation of 0.89 , concentrating close to the mean. It is possible to consider that the panelists are homogeneous and that appearance was not an attribute well accepted by the panelists.

The aroma obtained scores of 6.12 and 7.48, higher score among the evaluated attributes for the juices, in the random effect the aroma was the one that presented the lowest variability of the tasters and the lowest standard deviation. Thus, it can be said that variability is concentrated close to the average and therefore, we have that the panelists are homogeneous. It was possible to verify that the aroma was the attribute with better acceptability for both juices.

The residue of the aroma attribute showed greater variability and standard deviation between the attributes, it can be considered that the other attributes/factors influenced the juice notes. Regarding the standard deviation, the sample values are well distributed around the mean, but it is not homogeneous.

Table 5. Estimation of fixed and random parts of sensory attributes with random effect on the intercept (variable response are attributes).

\begin{tabular}{ccccccccc}
\hline & \multicolumn{2}{c}{ Appearance } & \multicolumn{2}{c}{ Aroma } & \multicolumn{2}{c}{ Flavor } & \multicolumn{2}{c}{$\begin{array}{c}\text { Overall } \\
\text { impression }\end{array}$} \\
\hline Random part & Variance & s.d. & Variance & s.d. & Variance & s.d. & Variance & s.d. \\
Panelists(Intercept) & 0.80 & 0.89 & 0.46 & 0.68 & 1.67 & 1.29 & 1.46 & 1.21 \\
Residue & 3.14 & 1.77 & 3.93 & 1.98 & 3.50 & 1.87 & 2.89 & 1.70 \\
& Estimate & s.e. & Estimate & s.e. & Estimate & s.e. & Estimate & s.e. \\
Fixed part & 7.32 & 0.20 & 7.48 & 0.21 & 7.06 & 0.23 & 7.29 & 0.21 \\
(Intercept) & -2.96 & 0.26 & -1.36 & 0.29 & -1.66 & 0.27 & -2.43 & 0.25 \\
$\begin{array}{c}\text { Mango juice with } \\
\text { probiotic }\end{array}$ & & & & & & & & \\
\hline
\end{tabular}

Source: Authors.

The flavor attribute and overall impression showed high variability of the panelists, having as values of the estimated variance in 1.67 and 1.46 respectively. In the residues, the flavor attribute presented a variability greater than the overall impression with a value of 3.50, while the overall impression value was 2.89. Most of the variation was due to the panelists, and the other part due to other factors. 
Taking into consideration the flavor attribute that had greater variability of the panelists and a high standard deviation, it can be said that the data are scattered around the mean, being most of the variation due to the panelists. It was also observed the grades attributed to the juices, 5.40 for the juice with probiotic and 7.06 for the juice without probiotic, which were different, it is noted that the flavor of the juice with probiotic suggested to the panelists a trend of "neither liked/ nor disliked".

In the fixed part it is possible to observe the estimates of the scores of each sample, in appearance, it is estimated that for each test the score attributed to the juice without decreasing will be on average 7.32 , and for the juice with probiotic the score will decrease on average 2.96.

It is observed that for each test the aroma will have an average estimate of 7.48 for the juice without probiotic, and for the juice, with probiotic, the score will decrease on average to 1.36. The flavor will have an estimate of 7.06 for the juice without probiotic and in the juice with the culture will decrease 1.66. And finally, the overall impression that will have an estimate of 7.29 for the juice without probiotic and for the juice with the culture will decrease 2.43.

\section{Discussion}

According to the results, the $\mathrm{pH}$ values showed a significant difference between the samples, and the mango juice with the addition of Bifidobacterium- BB12 was higher because the xanthan gum and sodium alginate used as encapsulation and coating material, enabled the highest final $\mathrm{pH}$. The results of the present study are in agreement with Miranda et al. (2019) in a study with orange juice added with Lactobacillus casei encapsulated with sodium alginate where the pH was also higher than the control without probiotic.

Concerning total soluble solids, total solids, and titratable acidity, a significant difference was observed between the juices. The reduction of these compounds may be related to probiotic microorganisms, which when consuming the citric acids and/or sugar present in the juice can produce small amounts of organic acids (Mousavi et al., 2011). Possibly with the decrease of the titratable acidity, the medium became more favorable for probiotics and resulting in a less acid product. The $\mathrm{L}^{*}$ values in the probiotic mango juice were higher possibly due to the use of the encapsulating agents used that have a whitish coloration (Dias et al., 2018).

According to Pimentel et al. (2011), the low viability of probiotic cultures in fruit juices is found in several studies and different alternatives have been used to overcome the survival problems of these microorganisms, including a selection of acidity resistant cultures, microencapsulation of probiotics, the addition of prebiotics, supplementation with substrates, $\mathrm{pH}$ adjustment of the medium and use of aseptic packaging. For a product to be considered a probiotic it must have a viable cell count close to $\log 8 \mathrm{CFU} \mathrm{mL}^{-1}$ (Brazil, 2018). In the present work, microencapsulation acted as a good protective barrier for probiotic culture, since viability presented values above the legislation.

The addition of microencapsulated probiotic culture resulted in decreased acceptance in most attributes. These results may be related to a reduction in acidity, and an increased in luminosity and $\mathrm{pH}$.

Santos et al (2019) in a study with probiotic sugarcane juice added from prebiotics, showed that the formulation that contained only the probiotic (Lactobacillus casei) presented in his sensory analysis notes of 4.93 to 6.31 , the addition of the culture resulted in a more acidic, turbid, lighter coloring and less accepted by panelists. On the other hand, according to Pimentel et al. (2015) the formulations of clarified apple juice with probiotic in glass and plastic packages presented notes between 6.7 and 7.0, indicating that panelists "liked moderately and slightly", and were in doubt as to the purchase intention.

Machado and Rizzatto (2019) observed that in the acceptance test, with 52 tasters, of passion fruit juice fermented with not sweetened L. casei, $42.3 \%$ presented frequency in the acceptance zone, $5.8 \%$ in the indifference zone, and $51.9 \%$ in the rejection zone. The tasters commented that this sample presented to be very acidic and with a very pronounced flavor of 
passion fruit. The passion fruit juice fermented with $L$. casei sweetened with stevia and sucrose obtained greater acceptance than the non-sweetened.

In this work, the unstructured hedonic scale was used to evaluate juices, as it allows freedom for panelists to express their sensory perceptions, reduce contextual effects and present the data with less deviation from normality (Pimentel et al., 2015). It is understood that the overall appearance and impression notes for probiotic juice tend to be low compared to juice without probiotics. The statistical analysis showed that the panelists preferred the juice without probiotics, but it is noted that the panelists liked the aroma of the juice with probiotics, and had doubts about the flavor.

\section{Final Considerations}

The use of mixed models for the analysis of acceptance test data offered important results on the variability of the panelists about each attribute. Through the random effect, it was possible to identify which was the attribute most accepted by the tasters, in addition to providing statistically significant differences at the level of $5 \%$ in the part of the fixed effect.

With the results provided by the mixed model, it was observed that the tasters preferred the juice without probiotics and would certainly buy the product, but about the juice with probiotics, they liked the aroma, and presented doubts about the flavor and consequently the intention to buy the product.

For a more complete sensory analysis, sensory panels should be made to highlight specific characteristics of mango juice with probiotics, which have not been studied in this work.

\section{Acknowledgments}

The authors are grateful to CAPES for supporting this project; and Chr. Hansen which supplied probiotics.

\section{References}

Anekella, K., \& Orsat, K. (2013). Optimization of microencapsulation of probiotics in raspberry juice by spray drying. LWT-Food Science and Technology, 50, 17-24. https://doi.org/10.1016/j.lwt.2012.08.003.

Ares, G., \& Varela, P. (2017). Trained vs. consumer panels for analytical testing: Fueling a long lasting debate in the field. Food Quality and Preference, 61, 79-86. https://doi.org/10.1016/j.foodqual.20196.10.006.

AOAC, (2004). Official methods of analysis. (15th ed.).

Brazil, (2018). Agência Nacional de Vigilância Sanitária (ANVISA) - RDC nº 241, de 26 de julho de 2018. Requisitos para comprovação da segurança e dos benefícios à saúde dos probióticos para uso em alimentos. Diário Oficial da União, Dec. 144, 2018.

Brockhoff, P. B., Schlichb, P., \& Skovgaard, I. (2015). Taking individual scaling differences into account by analyzing profiledata with the Mixed Assessor Model. Food Quality and Preference, 39, 156-166. https://doi.org/10.1016/j.foodqual.2014.07.005.

Costa, M. G. M., Fonteles, T. V., de Jesus, A. L. T., \& Rodrigues, S. (2013). Sonicated pineapple juice as substrate for L. casei cultivation for probiotic beverage development: Process optimisation and product stability. Food Chemistry, 139, 261-266. https://doi.org/ 10.1016/j.foodchem.2013.01.059.

Dias, C. O., Almeida, J. S. O., \& Pinto, S. S. (2018). Development and physico-chemical characterization of microencapsulated bifidobacteria in passion fruit juice: A functional non-dairy product for probiotic delivery. Food Bioscience, 24, 26-36. https://doi.org/10.1016/j.fbio.2018.05.006.

Guimarães, J. T., Balthazar, C. F., Silva, R. et al. (2020). Impact of probiotics and prebiotics on food texture. Current Opinion in Food Science, 33, 38-44. https://doi.org/10.1016/j.cofs.2019.12.002.

IDF (2007). International Dairy Federation - Bulletin of the IDF $\mathrm{n}^{\mathrm{o}} 411 / 2007$. Selective enumeration of bifidobacteria in dairy products: development of a standard method.

Kingwatee, N., Apichartsrangkoon, A., Chaikham, P. et al. (2015). Spray drying Lactobacillus casei 01 in lychee juice varied carrier materials. LWT - Food Science and Technology, 62, 847-853. https://doi.org/10.1016/j.1wt.2014.12.007.

Kuznetsova, A., \& Brockhoff, P. B. (2015). Linear mixed models in sensometrics. Kgs. Lyngby: Technical University of Denmark. (DTU Compute PHD2015; No. 374). 
Research, Society and Development, v. 10, n. 4, e4010413876, 2021

(CC BY 4.0) | ISSN 2525-3409 | DOI: http://dx.doi.org/10.33448/rsd-v10i4.13876

Machado, L. F., \& Rizzatto, M. L. (2019). Produção e análise físico-químicas de bebida probiótica de suco de maracujá. Cogitare, 2(1), 50-69. https://ojs.ifsp.edu.br/index.php/cogitare/article/view/1167.

Meilgaard, M., Civille, G. V., \& Carr, B. T. (1988). Sensory evaluation techniques, (2th ed). (pp. 9). CRC, Boca Raton.

Miranda, R. F., de Paula, M. M., \& da Costa, G. M. et al. (2019). Orange juice added with L. casei: is there an impact of the probiotic addition methodology on the quality parameters? LWT - Food Science and Technology, 106, 186-193. https://doi.org/10.1016/j.1wt.2019.02.047.

Mousavi, Z. E., Mousavi, S. M., Razavi, S. H. et al. (2011). Fermentation of pomegranate juice by probiotic lactic acid bacteria. World Journal of Microbiology and Biotechnology, 27(1), 123-128. https://doi.org/10.1007/s11274-010-0436-1.

Næs, T., Brockhoff, P. B., \& Tomic, O. (2010). Statistics for sensory and panelista science. John Wiley and Sons Ltd.

Oliveira, P. M., Leite Junior, B. R. C., Martins, E. M. F. et al. (2020). Mango and carrot mixed juice: a new matrix for the vehicle of probiotic lactobacilli. Journal of Food Science and Technology, 58, 98-109. https://doi.org/10.1007/s13197-020-04518-y.

Pereira, A. L. F., Maciel, T. C., \& Rodrigues, S. (2011). Probiotic beverage from cashew apple juice fermented with Lactobacillus casei. Food Research International, 44, 1276-1283. https://doi.org/10.1016/j.foodres.2010.11.035.

Pimentel, T. C., Madrona, G. S, Garcia, S., \& Prudencio, S. H. (2015). Probiotic viability, physicochemical characteristics and acceptability during refrigerated storage of clarified apple juice supplemented with Lactobacillus paracasei ssp. paracasei and oligofructose in different package type. LWT-Food Science and Technology, 63, 415-422. https://doi.org/10.1016/j.1wt.2015.03.009.

Pimentel, T. C., Prudêncio, S. H., \& Rodrigues, R. S. (2011). Néctar de pêssego potencialmente simbiótico. Alimentos e Nutrição Araraquara, 22(3), 455-464. https://www.researchgate.net/publication/236857649_Nectar_de_pessego_potencialmente_simbiotico

Pødenphant, S., Truong, M. H., Kristensen, P. B. et al. (2019). The mixed assessor model and the multiplicative mixed model. Food Quality and Preference, 74, 38-48. https://doi.org/10.1016/j.foodqual.2018.11.006.

Prates, F. C., Leite Junior, B. R. C., Martins, E. M. F. et al. (2020). Development of a mixed jussara and mango juice with added Lactobacillus rhamnosus GG submitted to sub-lethal acid and baric stresses. Journal of Food Science and Technology, 57(12), 4524-4532. https://doi.org/10.1007/s13197-020-04491-6.

Santos, M. A., Costa, G. M., Dias, S. S. et al. (2019). Pasteurised sugarcane juice supplemented with Lactobacillus casei and prebiotics: physicochemical stability, sensory acceptance and probiotic survival. International Food Research Journal, 26(4), 1315-1325. https://www.researchgate.net/publication/335589482_Pasteurised_sugarcane_juice_supplemented_with_Lactobacillus_casei_and_prebiotics_physicochemical _stability_sensory_acceptance_and_probiotic_survival.

Terçariol, F., Bitencourt, P., Marins, A. R., Matiucci, M. A. et al. (2020). Embutido cárneo fermentado tipo copa com utilização de probiótico e submetido à alta pressão. Brazilian Journal of Development, 6(6), 38878-38889. 